\title{
More Beyond the River for Jaffna
}

\section{Duleep Goonewardene}

Abstract: The Peninsula of Jaffna has the greatest concentration of dug wells in the Island. It is the only part in the entire country where no perennial rivers exist. Hence the area does not get accounted in the standard 103 River Basins. The surface bencath abounds in Karstic Limestone, at times, from almost surface level. This assists in storing the moderate rainfall, which runs to the sea or inland lagoons relatively slowly, due to its flat terrain. For centuries this region has been self sufficient in water to grow its own food and for consumption of a large population, without any water imports from outside. This paper investigates how this water can be preserved and enhanced for the future, by creating internal freshwater lagoons.

Keywords: Jaffna, River, Inland Lake, Aquifer, wells, groundwater, Arumugam

\section{Introduction}

The article below, first published in 1954, is essential in understanding the vision of the man, Eng.S. Arumugam, a former Deputy Director of Irrigation, one of the very few who have been honoured by the publication of a Commemoration Volume by the Institution of Engineers.

\subsection{River for Jaffna[1]}

Jaffna with a scanty rainfall which can sometimes be only $30^{\prime \prime}$ is different from the other parts of the Northern Province which enjoy a rainfall of over $60^{\prime \prime}$ during the year.

To convey the beneficial aspects of the abundant rainfall from one part of the province to another which is bereft of such bounty, is a legitimate aspiration for agricultural development.

The late K. Balasingham, Member of the Legislative Council, visualized early in the 1930 decade, the utilization of the lagoons by their conversion into fresh water lakes. His criterion was the oft-repeated saying of Parakrama Bahu the Great that "not a drop of rain should be allowed to flow into the ocean without profiting man".

These led to the consideration of the full utilization of the flood waters of Kanagarayan aru, the main river in the Northern Province. The aru has its source in Vavuniya and passes through Puliyankulam Mankulam area to fill Iranamadu tank.
The surplus flow enters the Elephant Pass lagoon, i.e., the lagoon to the East of Elephant Pass bridge, and goes to waste in the open sea, through the large bridge at Elephant Pass.

One day in the month of February 1949, a family travelling on the road had stopped on the road near the Elephant Pass bridge, for their picnic lunch. When washing their hands in the water the fond father was heard explaining to his little son's inquiries the reason for the presence of fresh water on the East side of the road in spite of the west side being open sea.

The little boy's impetuous response was "Let us bring some earth in our car and fill up the bridge, and then there will be fresh water always!"

That year the Kanagarayan aru had a copious flow; the Iranamadu irrigation tank had filled and been spilling. The surplus flow had filled the lagoon to the east of the road, and though the Iranamadu tank had stopped spilling in January, the water in the east lagoon was still fresh even in February. But it would soon become brackish due to sea water entry through the bridge unless some earth was brought and filling done.

That the water in the Eastern side of the road should remain fresh throughout the year, forms

Eng. Dulecp Goonewardene, C.Eng MIE (Sri Lanka), M.Eng (IHE, Delft), Assistant General Manager (Development -NWSEDB), Presently a Research Associate at Asian Institute of Technology - Thailand. 
the basis of the Elephant Pass Fresh Water Reservoir project on which work is in progress.

The Elephant Pass lagoon receives the waters of the Kanagarayan aru, Nethsali aru, Perementhal aru, Theravil aru, and other streams, and covers an area of about 11,400 acres stretching from Elephant Pass to Chundikulam.

It is bounded by Vanaekulam to the north and by the Karachchi lands to the south. With the erection of an obstruction near the bridge and suitable embankment spill near Chundikulam, the fresh water that enters the lagoon will form the Elephant Pass Fresh Water Reservoir. A link channel to the north through Mullian area connects this reservoir to the internal lagoon within the Jaffna peninsula usually known as the Vadamarachchi lagoon.

The Vadamarachchi lagoon is a long sheet of water connecting from Mulliyan in Pachchilaipalai, spreading through Chempiyanpattu, Eluthumadduval, Varani, Karaveddi, Vallai Veli, and connects with the sea near Thondamannar near Valvettithurai in Vadamarachchi. It also branches off at Sarasalai, and extends towards Jaffna town connecting up with the sea at Arialai near Chemmani.

It is about a mile wide, and as it extends more or less right through the heart of the peninsula, it is an ideal store house influences life in the peninsula. As a result of the 600 foot barrage recently completed at Thondamannar, entry of sea water has been cut off and is prevented from entering this internal lake, which was originally the Thondaiman Aar.

The nature of work envisaged to be done at Elephant Pass consists of three items:

A dam by the side of Elephant Pass bridge would conserve and save the flood waters of Kanagarayan aru, and also would in addition prevent any entry of sea water from the open sea in the west.

A one and a quarter mile roadway dam and spill built across the lagoon at its eastern end at Chundikulam would ensure the safe discharge of surplus flood waters and will also in addition prevent salt water ingress from the eastern ocean.
While these eastern and western structures would help to receive and store in safety, the fresh water flood flow, the third item, viz., a link canal will convey the water thus stored to the heart of the Jaffna peninsula.

On completion of these works, the Kanagarayan aru flood waters would first be utilized in leaching out the brackishness present in the Elephant Pass (primary or parent) reservoir, and in the Vadamarachchi (secondary or service) reservoir, simultaneously.

The primary reservoir with its clayey bed will respond much quicker than the secondary with its alluvial bed, to these leaching out measures. Though the process of leaching cannot obviously be concluded for some time, yet there would hardly be any delay in reaping the beneficial aspects.

The benefits will commence immediately, and improve more and more with each rain season. Moreover, it is well known that partially brackish water, though not fresh to the palate, is nevertheless useful for cultivation needs, as is the case with the water found in many wells in the coastal regions of the peninsula.

As days go by the heat of the sun during the months of February, March, April etc., will cause considerable evaporation in the reservoirs. Each day the amount of water lost in the secondary will be supplied to it by the primary through the canal, and the secondary will therefore continue to be full, (being supplemented every day), as long as flow from Elephant Pass reservoir is possible.

Such conditions could go on till the southwest monsoon in June, July cause enormous evaporation which it may not be possible to supplement.

In effect this will result in having an inland lake in the Jaffna peninsula. The benefits that will accrue to the lands in the Jaffna peninsula as a result of having a vast fresh water lake will be many-fold.

It would tend to make the underground water table copious and raise its level; the level of water in the wells would be higher as years go by. Moisture will be prevalent in the sub-soil. Plant life will become luxurious; gone will be the days when trees and coconut palms get scorched and drop in the hot season. 
That this work will benefit the agricultural development of the neighbouring area of over 15,000 acres is beyond doubt. It will also cause the flow of Kanagarayan aru waters from its source in Vavuniya district through the Jaffna district and over the spillway at Thondamannar and at Ariyalai in the outskirts of Jaffna town.

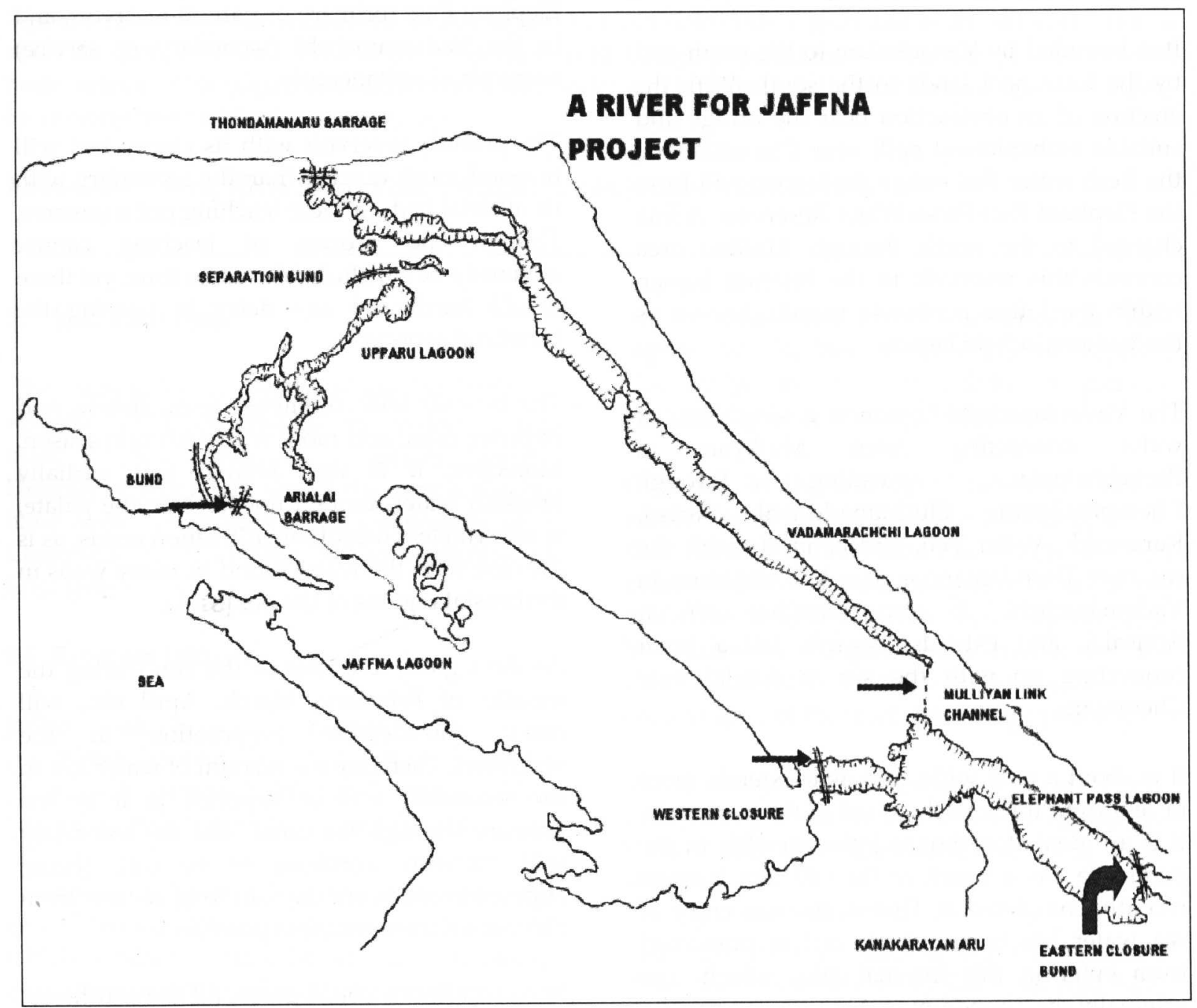

Figure 1

Figure 1 gives an indication of the project components, partially completed and then forgotten with the mists of time

\subsection{Marina Barrage - Singapore[2]}

“...the Marina Barrage will bring about three benefits - a new source of water supply, flood control and lifestyle attraction that will offer a host of recreational possibilities.

The barrage which comprises of a series of nine crest gates, will be built across the $350 \mathrm{~m}$ wide Marina Channel to keep out seawater. With the

\subsubsection{A new reservoir in the heart of the city}

barrage in place, the Marina Basin will turn into a body of freshwater through natural flushing in one or two years, similar to the existing Kranji and Lower Seletar Reservoir. The freshwater will then be treated using advanced membrane technology to ensure that it is safe for drinking. 
Combined with Seletar Reservoir, the new Marina Reservoir will help increase the water catchment areas from half to two-thirds of Singapore by 2009. The Marina Reservoir will meet more than $10 \%$ of the country's water demand.

With sound management practices in place, Singapore is one the few places where water in the public sector has flourished. As urbanisation takes over the world, it becomes important to find technological solutions with small-footprint and capacity for future expansion. Singapore has the highest population density in the world, yet the public does not suffer any inconvenience because the country's planners have always acted before it got too late. Water conservation, demand management, investment in alternate sources of water such as desalination and reclaimed water - these are often empty catchwords used in Asia. Not in Singapore."

The Marina Barrage was formally opened in November 2008.

The proper understanding of both articles above, is essential as we move forward towards new paradigms of water \& wastewater, essential for the $21^{\text {st }}$ century.

\section{Literature Review}

\subsection{Potential of the Shallow Karstic Aquifer of Jaffna Peninsula}

This aquifer is the most intensively utilized as well as the best studied one in this country and, as a result, much is known in respect of its variation in time and space. This aquifer gets fully recharged by the November - December rains of the North East monsoon.

No appreciable rainfall occurs after February, and the volume of stored water within the mounds of the karstic cavities tends to drop rapidly within less than three months. This significant loss of groundwater is because of the considerable karstification (porus limestone formation containing deep fissure and sinkholes) which intensifies the sub surface flow. This is the main problem in the Jaffna peninsula aquifer, especially around the coastal (karsts) of this Miocene Limestone, and hence this nomenclature for this aquifer. region, where the fresh water lens gets rapidly reduced in thickness, thus limiting water supplies in the dry season which extends up to August -September.

With rapidly increasing demands both for agriculture as well as urban and domestic use within the peninsula in the nineteen eighties, even by June -July the amount of good quality water available for domestic use had become restricted. Monitoring studies conducted in the seventies have confirmed a significant inbalance between draw off and recharge ratio. Water quality studies conducted in the mid eighties have shown enhanced levels of nitrate pollution in the densely settled Municipal areas within the peninsula. The number of open dug wells in the Jaffna Peninsular, had exceeded 100,000 by the early eighties.[3]

Of the above, about 17860 are estimated to be Agricultural wells, with a usage of 147000 mL/Year.( 403000 m3/day). [4]

For comparison, NWSDB \& WRB sources state that, water supply (supplied by pumping through many small schemes within the peninsula) is $2090 \mathrm{~m} 3 /$ day. [3]

The statistics amply demonstrate the relative independence of the inhabitants of the peninsula from the state sector, as regarding their requirement for water supply!

The Jaffna peninsula, whose waters have faithfully sustained its inhabitants for all purposes, may well have the highest density of wells, for water supply, anywhere in the world. It is this time tested, familiar and trusted method which needs to be protected, and preserved for posterity, bringing a higher degree of reliability and security.

It is of significance that, unlike most other locations in the island, quality (palatability) of the water takes precedence over quantity.

"The whole Jaffna peninsula is underlain by Miocene limestone formations which are generally 100 to $150 \mathrm{~m}$ thick and which are distinctly bedded, well jointed and are highly karstified. The shallow aquifer of the peninsula occurs in the channels and cavities

All the shallow groundwater found within the karstic cavities originates from the infiltration of rainfall, and this shallow groundwater forms 
mounds or lenses floating over the saline water. These water mounds or lenses reach their peak during the monsoon rains of November December. Of the annual recharge of rainwater which is between 10 to $20 \times 10^{7} \mathrm{cu} . \mathrm{m}$, around fifty percent eventually drains out to sea according to Balendran et al. (1968) and the remainder is used most intensively for agriculture and domestic purposes.

The aquifer boundary itself expands and contracts through the wet and dry seasons respectively. Monitoring studies have confirmed a significant inbalance between the draw-off and recharge rates as reported by Balendran (1969).

Approximately 80 percent of this groundwater is being used for high-value agriculture and the remaining 20 percent for domestic use including flushing demands of toilets in urban areas of Jaffna. Water quality studies have shown enhanced levels of nitrate pollution in domestic wells situated in the more densely settled Municipal areas of the peninsula as reported by Nagarajah et al 1988."

[3]

The Jaffna Karstic Limestone acts as a series of semi independent reservoirs joined with each other by complex series of 'conduits' of varying sizes, at various depths. Unlike other parts of the Island, Jaffna has no 'River Basin'. ( the River basin study by the Freedom from Hunger Campaign, concluded in the early ' $80 \mathrm{~s}$ had designated the entire peninsular as Basin No., 104).

The quality of water in wells, even at close proximity to each other, could vary by large amounts, especially in the levels of salinity. Hence using one well for drinking and another for other purposes is a quite common and accepted feature in the peninsular.

Thus, access had been ensured in the Thesawalamai law, where, even with land division, one still had the right to water from a well one has been using before, even though it be in another property.

"Within the Jaffna peninsula there are two large lagoons, the Vadamarachchi lagoon and the Upparu lagoon with surface areas of about 77 and 26 square $\mathrm{km}$ respectively. These are large shallow lagoons and cover a significant proportion $(10 \%)$ of the peninsula's land area of
1000 square $\mathrm{km}$. These lagoons have openings to the sea and are salt water lagoons but during the north-east monsoon rain water from their catchment areas also collects in them. The total catchment area of these lagoons is about $50 \%$ of the area of the Peninsula." [5]

"Finding suitable locations for wells in the Peninsular remains a challenging task due to the inherent complexities of the system and the fact that the thickness of the freshwater lens among other factors has a bearing on the quality of the groundwater extracted" [4]

\subsection{Threads of History of the River for Jaffna[5]}

The earliest known recorded observation about improving the fresh water situation in the Jaffna Peninsula was made nearly 350 years ago in "A Report of the journey from Colombo to Manaar, Jaffnapatnam and its subordinate posts and forts by Hendrile van Reede, Captain to Governor Rijckloff van Goens, 01 December $1665^{\prime \prime}$ in which he states:

"A dike to contain the sea at Condemanaer and Navacolli, with sluices to claim the rain water and a canal to the salt pans at Nieweli would create more useful arable land."

Van Reede suggests a barrage at Thondamannaru and another at Navatkuli (Arialai) to convert Vadamarachi and Upparu lagoons into freshwater lagoons, and a separate canal for salt water from the sea to the Upparu salterns

......In the 1930s and 1940s the Divisional Irrigation Engineer, Webb, produced detailed plans for barrages at Thondamannaru and Ariyalai. The scheme was supported in the State Council by Balasingham who was a member of the Council, but the war intervened and construction work on the Thondamannaru Barrage commenced only in 1947 and was completed in 1953, and the Ariyalai Barrage was completed in 1955. However these Barrages are no longer functional as the wooden gates have perished and sea water passes through them freely.

If we are to increase the availability of fresh water in the Jaffna peninsula we need to look at sources alternative to rain in the peninsula. South of the peninsula is the sea water Elephant Pass Lagoon which is relatively shallow but has 
a surface area of about 77 square $\mathrm{km}$. It has a catchment area of about 940 square $\mathrm{km}$ in the mainland Vanni, mainly consisting of the Kanakarayan Aru and three smaller streams. During the north-east monsoon these streams discharge the surplus rain water from the Vanni into the Elephant Pass lagoon. From this lagoon this fresh water flows into the sea through the eastern end at Chundikulam and formerly also through the western end Elephant Pass bridge, and is at present being wasted.

During the 1960's a scheme was proposed to utilise the monsoon rain water running to waste from the Elephant Pass lagoon, for the benefit of the Jaffna peninsula.

Key points of the scheme and details of the work done at that time are as follows:

- Close off the openings in the road and rail bridges in the Elephant Pass causeway at the western end of the Elephant Pass lagoon to prevent fresh water going to the sea from this end.

(This work was completed).

- Build a bund at the eastern end of the Elephant Pass lagoon at Chundikulam to prevent fresh water going to the sea at that end and also provide a spillway to discharge excess flood water to the sea.

(This work was completed and Elephant Pass lagoon became a fresh water lagoon for a few years but unfortunately the bund was breached by subsequent heavy floods, thus allowing sea water access since then).

- Excavate a 12 metre wide, $4 \mathrm{~km}$ long channel, called the Mulliyan Link Channel, from the northern side of the Elephant Pass lagoon to convey fresh water from the Elephant Pass lagoon to the southern end of the Vadamarachchi lagoon, including regulatory gates to control the flow.

(Unfortunately this work was never completed. About $80 \%$ was completed when funds ran out and work stopped).
- Refurbish the existing Thondamanaru Barrage (where the northern end of Vadamarachchi lagoon joins the sea) to make it watertight, and improve the discharge gates to allow for discharge of flood water. This will make Vadamarachchi lagoon a fresh water lagoon.

(This work was carried out but the present condition of the barrage is that it is no longer watertight and allows sea water to enter the lagoon).

- Provide a spillway and gates at the southern end of Upparu Lagoon where it connects to the sea, near Arialai. This will make Upparu lagoon a fresh water lagoon. Provide a link channel between Vadamarachchi and Upparu lagoons so that fresh water from Elephant Pass lagoon can be supplied to Upparu lagoon.

(The spillway and gates were constructed but the present condition of the gates is that it is no longer watertight and allows sea water to enter Upparu lagoon).

The scheme was only partially completed in the 1960 's and the main key element of the Mulliyan link channel to convey fresh water from Elephant Pass lagoon to Vadamarachchi lagoon was never completed. In the brief period that Vadamarachchi and Upparu were fresh water lagoons the benefits to the peninsula were noticeable and many saline wells became potable water wells. The present situation is that the barrages at Thondamanaru and Arialai are no longer watertight and are allowing sea water to enter these lagoons freely.

\section{Project benefits}

The benefits of completing this project include the following:

a About 8100 hectares of land is cultivated with paddy in the Jaffna peninsula. This cultivation is entirely rain fed unlike paddy cultivation on the mainland which is watered by irrigation channels. As it is rain fed, the yield per acre in Jaffna is very poor and is only about one-third of the average yield per acre on the mainland. If the 
Vadamarachchi and Upparu lagoons become fresh water lakes, the water table and water quality in the wells will improve, and using lift irrigation it will be possible to irrigate these paddy fields without depending purely on the rain. The potential for improvement in the yield is staggering.

a About 4400 hectares of land bordering the Vadamarachchi and Upparu lagoons are uncultivable at present as they are saline. When these become fresh water lagoons, after the salt is leached out of the soil, it will be possible to cultivate this land with cash crops and paddy.

口 There will be a dramatic improvement in the water quality of the $30 \%$ of the Jaffna wells which are now saline. In many cases the water will become suitable for domestic use and agricultural use, increasing the acreage under agricultural cultivation.

口 In the existing wells it will be possible to increase the amount of daily pumping without the water going saline, thus increasing agricultural cultivation and livestock production.

- Fresh water prawn farming can commence on the banks of the lagoons, with potential for export earnings.

- Converting Elephant Pass lagoon into a $77 \mathrm{sq} \mathrm{km}$ fresh water lagoon will provide fresh agricultural possibilities on both sides of the lagoon i.e. the Jaffna peninsula side on the north, as well as the Vanni side on the south, once the salinity has been leached out of the soil.

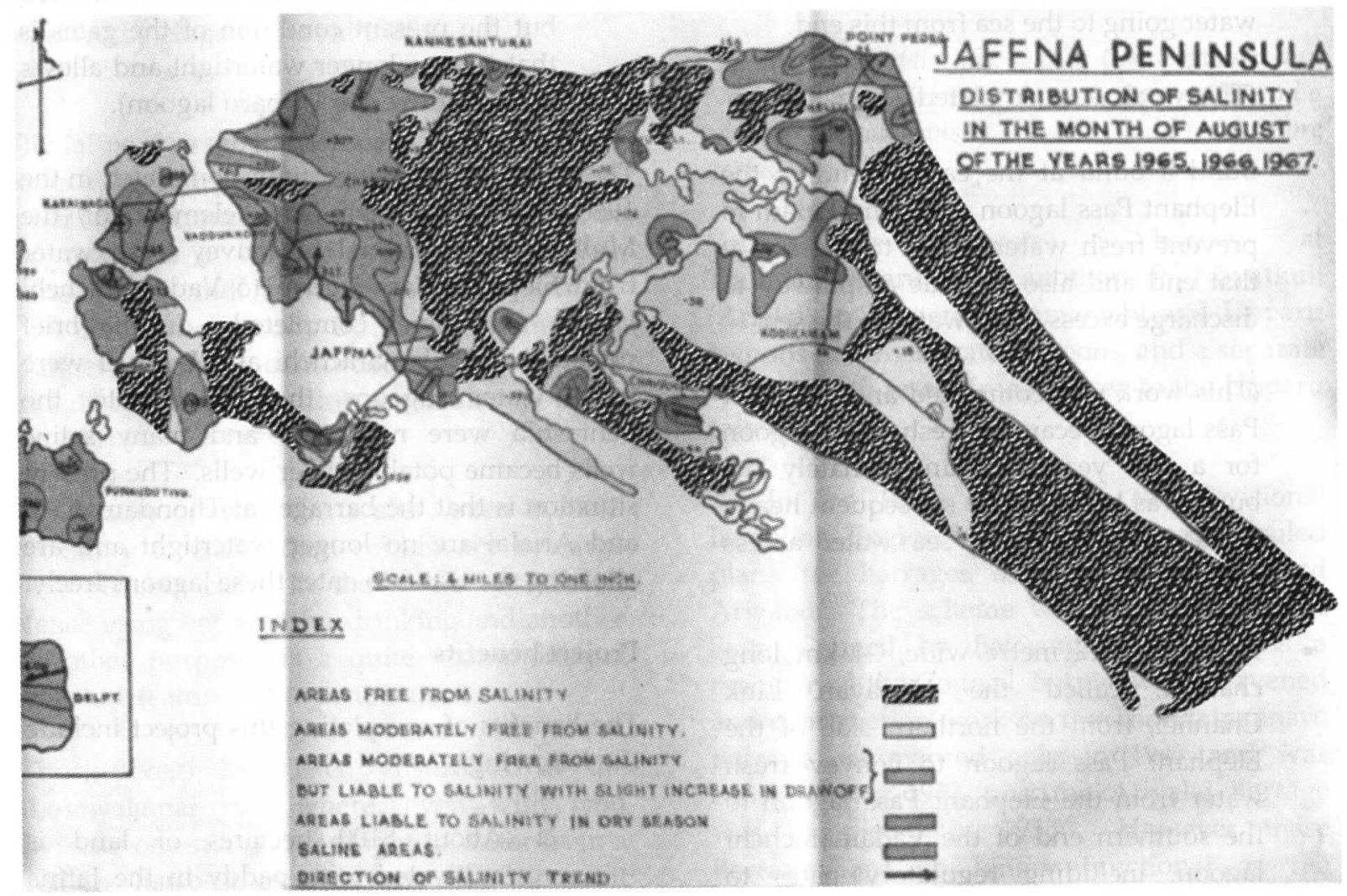

Figure 2

(Balendran ,Sirimanne \& Arumugam 1968- Water Resources board Booklet-Adapted)

Figure 2 gives a good picture of the excellent control of salinity during the few years when the project was functioning, albeit partially. It also gives a foretaste of what could be expected, of the quality of water once the project is completed. 


\section{Recent Attempts at Scheme Revival}

In January 1983 a report was submitted to the President of Sri Lanka, J R Jayawardene urging the completion of the scheme. The President convened a meeting in May 1983 at which he directed the Government officials present to implement the scheme. Unfortunately the 1983 internal disturbances occurred shortly thereafter, and the implementation did not proceed.

In July 2003 the then Minister for Irrigation and Water Management, Gamini Jayawickrema Perera, after visiting the project site was to submit a cabinet paper for the completion of the project. $\mathrm{He}$ described it as an "all embracing solution for water problems in Jaffna". Due to change of Government shortly thereafter, no further progress was made on project implementation.

In October 2007 at the Annual Sessions of the Institution of Engineers, Sri Lanka, held in Colombo, a Resolution was passed which urged the Government to complete this Project.
The Pugwash Conference held in Colombo in November 2007, passed the following beautifully worded and meaningful resolution."This Pugwash Workshop resolves to recommend to the Government of Sri Lanka that the project known as 'A River for Jaffna' that was started some fifty years ago, and almost completed, but is now in a state of disuse and abandonment, should be restored without delay, as a most important step towards including Sri Lankans of the Jaffna peninsula in the development and enjoyment of the natural resources of the country, thereby contributing to early achievement of a durable peace."

Table No 1, produced by the United Nations on the "Water Supply to the City of Tomorrow" in comparing it with 'the City of Today 'gives ample thought on which paths to take, in the approach to integrated water management. 
Table 1 - Comparison of Present \& Future Water supply

\begin{tabular}{|c|c|c|c|}
\hline \multicolumn{2}{|l|}{ Water Supply } & City of Today & City of Tomorrow \\
\hline \multicolumn{4}{|c|}{ Urban Water Management Organization } \\
\hline & $\begin{array}{l}\text { Organization } \\
\text { al Structure }\end{array}$ & $\begin{array}{l}\text { Separate entities } \\
\text { for different types } \\
\text { of water }\end{array}$ & $\begin{array}{l}\text { One entity for' Water' covering entire Urban } \\
\text { area }\end{array}$ \\
\hline & & $\begin{array}{l}\text { Covering entire } \\
\text { urban area }\end{array}$ & $\begin{array}{l}\text { City subdivided in water management units } \\
\text { (WMU) with high level of responsibility }\end{array}$ \\
\hline & Units & & Water is a tradable good between units \\
\hline & & $\begin{array}{l}\text { Depending on } \\
\text { preference of } \\
\text { water entities }\end{array}$ & $\begin{array}{l}\text { Determined by possibilities to manage water } \\
\text { within a unit }\end{array}$ \\
\hline & Philosophy & $\begin{array}{l}\text { Various types of } \\
\text { water have no } \\
\text { relationship }\end{array}$ & $\begin{array}{l}\text { Various types of water are part of the same } \\
\text { cycle and serve various purposes at different } \\
\text { times }\end{array}$ \\
\hline \multicolumn{4}{|c|}{ Drinking Quality } \\
\hline & Quality & $\begin{array}{l}\text { One quality for all } \\
\text { uses }\end{array}$ & $\begin{array}{l}\text { One quality for drinking, a second quality for } \\
\text { other uses }\end{array}$ \\
\hline & Distribution & $\begin{array}{l}\text { Underground } \\
\text { piping system, } \\
\text { vendors }\end{array}$ & $\begin{array}{l}\text { Drinking water through shops. Second quality } \\
\text { through piping system }\end{array}$ \\
\hline & Origin & $\begin{array}{l}\text { From wherever } \\
\text { available }\end{array}$ & From nearby \\
\hline \multicolumn{4}{|l|}{ Wastewater } \\
\hline & Quality & $\begin{array}{l}\text { Any quality } \\
\text { wastewater is } \\
\text { accepted }\end{array}$ & $\begin{array}{l}\text { Only 'clean' wastewater is accepted. } \\
\text { Dischargers responsible for quality of } \\
\text { wastewater submitted }\end{array}$ \\
\hline & Collection & $\begin{array}{l}\text { Collection from } \\
\text { domestic and } \\
\text { industrial origin to } \\
\text { point of discharge } \\
\text { or (central) } \\
\text { treatment }\end{array}$ & $\begin{array}{l}\text { Collection of 'clean' wastewater within the } \\
\text { WMU to point of further processing } \\
\text { Specific waste flows kept separate }\end{array}$ \\
\hline \multirow[t]{2}{*}{, } & Treatment & $\begin{array}{l}\text { Predominantly of } \\
\text { the activated } \\
\text { sludge type }\end{array}$ & $\begin{array}{l}\text { Further processing determined by the reuse } \\
\text { recovery options and the specific use of the } \\
\text { water within the WMU } \\
\text { Indirect reuse is objective }\end{array}$ \\
\hline & Discharge & $\begin{array}{l}\text { Into nearest } \\
\text { surface water }\end{array}$ & $\begin{array}{l}\text { Depending on possibilities within WMU eg: } \\
\text { irrigation. Groundwater recharge. surface } \\
\text { water discharge }\end{array}$ \\
\hline \multicolumn{4}{|l|}{ Rainwater } \\
\hline & Approach & $\begin{array}{l}\text { Removal as quick } \\
\text { as possible so as } \\
\text { not to have } \\
\text { flooding problems }\end{array}$ & Make best possible use of this resource \\
\hline & Processing & $\begin{array}{l}\text { Removal into } \\
\text { sewer }\end{array}$ & $\begin{array}{l}\text { Collection, temporary storage, followed by } \\
\text { some type of treatment }\end{array}$ \\
\hline & Usage & none & $\begin{array}{l}\text { Various options, e.g.: street cleaning, green } \\
\text { areas ,ground water recharge, or } \\
\text { drinking/process water }\end{array}$ \\
\hline
\end{tabular}

Water Supply of the future should not be viewed in the traditional narrow sense of 'Supplying pipe borne water', but in the broader aspect of it acting as a catalyst for multiple ground breaking possibilities. 


\section{Conclusions}

During the rains when the lagoons at Upparu and Vadamaratchy fill up, it is common for the 'good' wells to become sweeter and the 'brackish' to become better. Not only the Peninsular, but the Paranthan deep confined groundwater basin to the South in the Wanni too, is bound to benefit.

Hence having a system which would naturally and continuously feed the existing aquifers, maintaining a thicker freshwater lens, literally under our feet, coupled with measures for prevention of Nitrogen and Phosphorous leachate from septic tanks and excess artificial fertilizer, would be a sound solution for both the quantity and quality of Groundwater of the peninsular.

In fact this could be viewed as a planned, mega rainwater harvesting, recharge, storage, treatment and conveyance system, all rolled up in one, using the fullest potential of the karstic nature of the underground limestone .

The attraction of both internal and foreign Tourism around a water Body with direct access to Chundikulum nature sanctuary, would ensure a natural movement of people towards the area.

Opportunities will open up for embittered minds to be redirected, and transform skills and youthful vigour into many productive endeavours.

Being an Island nation, the sea level rise due to global warming would affect the groundwaters of our entire coastline to various degrees. However being so flat and only a few meters above Mean sea Level, the Jaffna Peninsular would be one of the earliest affected. Hence there is a dire need to keep the groundwater in the underlying Karstic aquifer as good and as high as possible at all times, by an integrated Management of its water and wastewater.

An integrated project would be by far superior, than a proposal of an Australian Consultant,(who has either completely disregarded or was oblivious of the' River for Jaffna' concept) which envisages laying long pipelines from the Iranamadu Reservoir, and pumping water into the Peninsular, further extended under sea to the Islands, merely for water supply.

This needs to be viewed also from the angle of security of a single arterial pipe, subject to willful or natural damage, which could 'dry $u^{\prime}$ the Jaffna Penninsular without warning.

An expanded vision of the River for Jaffna, would bring not only "Water supply, Flood control and New lifestyle attraction" as in the case of Singapore's Marina park, but pave the way for Agricultural rejuvenation of long neglected areas .

Sufficient water, along with the proper investments and the resourcefulness of the inhabitants could make this happen before long.

What better opportunity awaits, to implement the vision for water for the people of the Peninsular, from an Engineer, born and bred on the same native soil.

The Challenge now before all concerned professionals and politicians alike is, "IF NOT NOW, THEN WHEN"?

\section{Acknowledgements:}

1. Eng.Thirumugam Arumugam (son of $\mathrm{S}$ Arumugam)- For Personal correspondence on the subject.

2. Eng. D.L.O Mendis- For instilling an abiding interest to delve into the fascinating Hydraulic Civilization of Sri lanka

\section{References:}

1. Arumugam S, A River for Jaffna(1954), republished in "The Island", 14-4-2002

2. Asian Water\& Sewage

3. Panabokke C.R, Perera A.P.G.R.L, Groundwater Resources of Sri lanka, 2005

4. Punthakey JF, Gamage N.P.D, Coupled flow and salinity Transport modeling and Assessment of Groundwater availability in the JaffnaPeninsular, Sri lanka-32nd WEDC Conference-2006

5. Arumugam T- A River for Jaffna- Pugwash Conference-2007 